\title{
Gonadotrophin surge-induced upregulation of mRNA for plasminogen activator inhibitors 1 and 2 within bovine periovulatory follicular and luteal tissue
}

\author{
M. P. D. Dow ${ }^{1}$, L. J. Bakke' ${ }^{2}$, C. A. Cassar ${ }^{1}$, M. W. Peters ${ }^{1}$, \\ J. R. Pursley ${ }^{1}$ and G. W. Smith ${ }^{1,2 *}$ \\ Departments of ${ }^{1}$ Animal Science and ${ }^{2}$ Physiology, Michigan State University, East Lansing, \\ MI 48824-1225, USA
}

The serine proteinases, tissue-type (tPA) and urokinase (uPA) plasminogen activator, are implicated in the ovulatory processes via their ability to convert plasminogen to its active form, plasmin. One mechanism for regulation of plasmin-directed ovarian extracellular matrix remodelling during follicle rupture and corpus luteum formation is through inhibition of plasminogen activation by the plasminogen activator inhibitors (PAI-1 and PAI-2). The effect of the preovulatory gonadotrophin surge on the temporal and spatial regulation of expression of PAI-1 and PAI-2 mRNA and PAI activity in preovulatory bovine follicles and new corpora lutea collected at 0, 6, 12, 18, 24 and $48 \mathrm{~h}$ after a GnRH-induced gonadotrophin surge was examined. Both PAI-1 and PAI-2 mRNAs were upregulated markedly after the gonadotrophin surge, with the highest expression observed in follicles collected at about the time of ovulation (24 h) and in corpora lutea (48 h). PAI-1 mRNA was localized primarily to the thecal layer of preovulatory follicles. In contrast, PAI-2 mRNA was localized specifically to the granulosa cell layer. Significant PAI activity was detected in follicle extracts, but temporal or spatial differences in PAI activity were not detected in response to the gonadotrophin surge. These results indicate that PAI-1 and PAI-2 mRNAs are upregulated in preovulatory bovine follicles after the gonadotrophin surge in a cell-specific way. Regulation of PAI-1 and PAI-2 may help to control plasminogen activator activity associated with ovulation and early corpus luteum formation.

\section{Introduction}

The oocyte must be liberated from the preovulatory follicle for fertilization and subsequent pregnancy to occur. The gonadotrophin surge initiates the production of proteinases that mediate the degradation of the extracellular matrix and cellular remodelling required for follicular rupture and corpus luteum formation. One such family of proteinases implicated in the above processes is the plasminogen activators. The plasminogen activators consist of two enzymes, tissue-type (tPA) and urokinase (uPA) plasminogen activator, that convert ubiquitous plasminogen into the broadspectrum serine proteinase, plasmin. One mechanism for the temporal and spatial regulation of plasminogen activator activity is through the action of two members of the serine protease inhibitor (serpin) gene family, plasminogen activator inhibitors 1 and 2 (PAI-1 and PAI-2). Both inhibitors bind to UPA or IPA in a 1:1 stoichiometry in vitro. Structurally, both serpins have an exposed reactive centre loop (RCL) of approximately 20 amino acids, which

*Correspondence

Email: smithge7@msu.edu inhibits the activity of plasminogen activators when inserted into the active site of the enzymes (Loskutoff et al., 1988). In vivo, PAl-1 is an efficient inhibitor of both tPA and UPA, whereas PAI-2 is thought to inhibit UPA primarily (Holmberg et al., 1978; Lecander et al., 1984). PAI-2 exists as both an intracellular non-glycoslyated form and a secreted glycosylated form with different biological activities (Kruithof et al., 1987). Furthermore, PAl-2 is 20-100-fold less efficient in inhibiting plasminogen activator activity than PAI-1 (Kruithof et al., 1986).

Evidence indicates that PAI-1 may play a key role in the temporal and spatial regulation of plasminogen activator activity in rat preovulatory follicles during the periovulatory period. mRNA for tPA and PAI-1 shows parallel increases until just before the time of ovulation, when PAI-1 mRNA abundance decreases markedly but tPA mRNA remains high. The spatial localization of tPA and PAI-1 is also distinct in rat preovulatory follicles; activity for tPA is associated primarily with granulosa cells, whereas PAI-1 immunoreactivity is concentrated predominantly in the thecal cells of preovulatory follicles collected near the time of ovulation (Peng et al., 1993; Liu, 1999). This differential regulation of $\mathrm{PAA}$ and $\mathrm{PAI}-1$ may provide a temporal and spatial window of increased tPA activity that may be 
important for mediating the ovulatory process in rats. Even less information is available about the intrafollicular localization and regulation of PAI-2 mRNA during the periovulatory period.

To date, the periovulatory regulation and potential roles of PAI-1 and PAI-2 in the regulation of remodelling of the ovarian extracellular matrix, which are characteristic of follicle rupture and corpus luteum formation, are not completely understood. Therefore, the aim of the present study was to determine the effect of the preovulatory gonadotrophin surge on localization and regulation of PAI-1 and PAI-2 mRNAs and PAI activity in bovine periovulatory follicular and luteal tissue.

\section{Materials and Methods}

\section{Animal care}

Mature Holstein cows (Bos taurus) aged $\geqslant 2$ years were fed a balanced corn silage diet and housed at the Michigan State University Beef Cattle Research Center during the course of the experiments. All experiments were approved by the All University Committee on Animal Use and Care at Michigan State University (Approval 04/98-056-00).

\section{Experimental model}

Follicle development and timing of the preovulatory gonadotrophin surge were synchronized in Holstein cows using the Ovsynch procedure (Pursley et al., 1997). In brief, $100 \mathrm{mg} \mathrm{GnRH}$ was injected to start a new wave of follicle growth and, thus, a new dominant follicle. After 7 days, $25 \mathrm{mg} \mathrm{PGF}_{2 \alpha}$ was administered to regress corpora lutea. A second $\mathrm{GnRH}$ injection was administered $36 \mathrm{~h}$ later to induce an LH surge, resulting in ovulation of the dominant follicle. Daily ultrasound analyses were performed after the first $\mathrm{GnRH}$ injection until the time of follicle collection to verify follicle synchrony and to exclude animals that turned over a new follicular wave before the second $\mathrm{GnRH}$ injection. Average time of ovulation is approximately $29 \mathrm{~h}$ after the second GnRH injection (Pursley et al., 1995). Ovaries containing ovulatory follicles or new corpora lutea were collected by colpotomy (under epidural anaesthesia) at $0,6,12,18,24$ and $48 \mathrm{~h}$ (corpora lutea) after the second $\mathrm{GnRH}$ injection. Blood samples were collected at the time of $\mathrm{PGF}_{2 \alpha}$ injection and at the time of the second $\mathrm{GnRH}$ injection. Serum progesterone concentrations in these samples were measured by radioimmunoassay (Diagnostic Products Corporation, Los Angeles, CA) to ensure that all animals included in the study responded to the PGF $2 \alpha$ injection with a decrease in serum progesterone concentration to $<1 \mathrm{ng} \mathrm{ml}^{-1}$, indicating corpus luteum regression. Intra- and interassay coefficients of variation were 5.6 and $9.1 \%$, respectively. Three blood samples at $15 \mathrm{~min}$ intervals were collected every $8 \mathrm{~h}$ beginning $16 \mathrm{~h}$ after the $\mathrm{PGF}_{2 \alpha}$ injection until the time of ovariectomy or $\mathrm{GnRH}$ injection, to verify that none of the animals included in the study underwent a preovulatory gonadotrophin surge before the second GnRH injection. A premature $\mathrm{LH}$ surge was not detected in any of the animals included in the $0 \mathrm{~h}$ (pregonadotrophin surge group). Blood samples were also collected every hour for $4 \mathrm{~h}$ after the second $\mathrm{GnRH}$ injection to confirm that a gonadotrophin surge was elicited by the second $\mathrm{GnRH}$ injection. In the other animals, the $\mathrm{LH}$ surge occurred after GnRH injection only, verifying control of timing of the gonadotrophin surge in our model system. Concentrations of serum LH were measured by radioimmunoassay (Matteri et al., 1987; Jimenez Krassel et al., 1999). Intra- and interassay coefficients of variation were 5.8 and $15.6 \%$, respectively.

\section{Tissue collection}

For mRNA quantification and proteinase inhibitor activity assay, ovaries containing the ovulatory follicle or new corpora lutea were collected at 0, 6, 12, 18, 24 and $48 \mathrm{~h}$ ( $n=5-6$ in each group) after the second $\mathrm{GnRH}$ injection. After ovariectomy, the ovulatory follicle or new corpus luteum was isolated by cutting away all remaining ovarian stroma and small follicles such that the ultrastructure at the apex of the follicle remained intact. The follicles were cut in half transversely. One half was used for total RNA isolation. For protein analysis, the other half was cut sagitally into two equal pieces, one containing the follicle apex and one the base. New corpora lutea collected at $48 \mathrm{~h}$ after $\mathrm{GnRH}$ injection were used for mRNA analyses only. Samples were frozen at $-80^{\circ} \mathrm{C}$ within $15 \mathrm{~min}$ of ovariectomy. For in situ hybridization, ovaries containing the ovulatory follicles were collected at 0,6 and $24 \mathrm{~h}(n=3$ in each group) after GnRH injection. Ovulatory follicles were dissected from the ovary, immersed immediately in embedding medium, frozen over liquid nitrogen vapour and stored at $-80^{\circ} \mathrm{C}$ until cut into sections.

\section{Preparation of CDNA probes for PAI-1 and PAI-2}

The nucleotide sequence of bovine PAI-1 has been reported (GenBank accession no. X16383). The reported sequence was used to prepare oligonucleotide primers, which were used in combination with RNA isolated from bovine corpora lutea in the RT-PCR to amplify a $491 \mathrm{bp}$ CDNA that encoded bovine PAI-1. A set of degenerate primers (CTCCTCRTTCACATCCAC and GCTTTATCCTTTCCGTGTMAA; $R=G+A ; M=A+C$ ) was designed based on the nucleotide sequence of PAI-2 from humans, rats and mice to obtain a bovine PAI-2 cDNA. These primers were used to amplify a 442 bp PAI-2 cDNA by RT-PCR from bovine luteal RNA. PCR products (PAI-1 and PAI-2) were subcloned into pBluescript $\mathrm{SK}(+)$ vectors (Stratagene, La Jolla, CA) and their identities and orientations were confirmed by fluorescent dye terminator sequencing. The partial bovine PAI-2 cDNA (GenBank accession no. AF416234) shared $84 \%$ identity with human PAI-2 
(Schleuning et al., 1987). In addition, a shorter PAI-2 cDNA (247 bp) was amplified from the PAI-2 cDNA using an internal primer and one original PAI-2 primer, and was subcloned and sequenced as described above.

\section{Characterization of PAI-1 and PAI-2 IRNA abundance}

Total RNA was isolated according to the manufacturer's instructions using the Trizol reagent (Invitrogen, Carlsbad, CA). Approximately $15 \mu \mathrm{g}$ pooled RNA from each sample per time point was subjected to northern blot analysis to determine transcript size and number, and to optimize the specificity of hybridization conditions (Sambrook et al., 1989). For quantitation of PAI-1 and PAI-2 mRNA abundance, $5 \mu \mathrm{g}$ total RNA from each sample was applied in duplicate to a Zeta probe nylon membrane (Bio-Rad, Hercules, CA) using a dotblot apparatus (Bio-Rad; Sambrook et al., 1989). Northern and dotblot analysis were performed using specific bovine PAI-1, PAI-2 or ribosomal protein L-19 (RPL19) [32P]-labelled cDNA probes generated by PCR. RPL19 was used for normalization purposes. Each $20 \mu \mathrm{l}$ $\mathrm{PCR}$ reaction included $1 \times \mathrm{PCR}$ buffer, $2.5 \mathrm{mmol} \mathrm{MgCl}_{2} \mathrm{I}^{-1}$, $1.6 \mu \mathrm{mol}{ }^{-1}$ each of dATP, dGTP, dTTP, $0.25 \mu \mathrm{mol}$ of each primer $\mathrm{I}^{-1}$, $100 \mathrm{pg}$ DNA template, $1.5 \mathrm{U}$ Taq polymerase and $0.825 \mu \mathrm{mol}\left[{ }^{32} \mathrm{P}\right] \mathrm{dCTP} \mathrm{I}^{-1}\left(3000 \mathrm{Ci} \mathrm{mmol}^{-1}\right.$; NEN ${ }^{\circledR}$ Life Science Products, Boston, MA). The amplification conditions were: $95^{\circ} \mathrm{C}$ for $5 \mathrm{~min} ; 94^{\circ} \mathrm{C}$ for $0.5 \mathrm{~min}, 52^{\circ} \mathrm{C}$ for $1 \mathrm{~min}$, $72^{\circ} \mathrm{C}$ for $1.5 \mathrm{~min}$ for 40 cycles; $72^{\circ} \mathrm{C}$ for $10 \mathrm{~min}$; hold at $4^{\circ} \mathrm{C}$. After amplification, the PCR samples were made up to $100 \mu \mathrm{l}$ with NETS $\left(150 \mathrm{mmol} \mathrm{NaCl}{ }^{-1}, 10 \mathrm{mmol}\right.$ EDTA $\mathrm{I}^{-1}$, $50 \mathrm{mmol}$ Tris $\left.\mathrm{I}^{-1}, 0.1 \%(\mathrm{w} / \mathrm{v}) \mathrm{SDS}\right)$ and the unincorporated ${ }^{32} \mathrm{P}$ was removed by spun column chromatography through G-50 Sephadex minicolumns (Sambrook et al., 1989). The membranes were incubated overnight at $42^{\circ} \mathrm{C}$ in $25 \mathrm{ml}$ prehybridization buffer $(50 \%(\mathrm{v} / \mathrm{v})$ formamide, $5 \times \mathrm{SSC}$ (saline-sodium citrate buffer: $1 \times \mathrm{SSC}$ is $0.15 \mathrm{~mol} \mathrm{NaCl} \mathrm{I-1}$ and 0.015 mol sodium citrate $\left.{ }^{-1}, \mathrm{pH} 7.0\right), 5 \times$ Denhardt's $^{-1}$ (single strength is $0.02 \%(\mathrm{w} / \mathrm{v})$ Ficoll, $0.02 \% \quad(\mathrm{w} / \mathrm{v})$ polyvinylpyrrolidone, $0.02 \%(\mathrm{w} / \mathrm{v}) \mathrm{BSA}), 0.05 \mathrm{~mol}$ sodium phosphate $\mathrm{I}^{-1}(\mathrm{pH} 6.9), 0.1 \% \quad(\mathrm{w} / \mathrm{v})$ SDS and $250 \mu \mathrm{g}$ denatured herring sperm DNA $\left.\mathrm{ml}^{-1}\right)$ ). The prehybridization buffer was discarded and $25 \mathrm{ml}$ fresh hybridization buffer $(50 \%(\mathrm{v} / \mathrm{v})$ formamide, $5 \times \mathrm{SSC}, 1 \times$ Denhardt's, $0.02 \mathrm{~mol}$ sodium phosphate $\mathrm{I}^{-1}, 0.1 \%(\mathrm{w} / \mathrm{v}) \mathrm{SDS}, 10 \%(\mathrm{w} / \mathrm{v})$ dextran sulphate, $100 \mu \mathrm{g}$ denatured herring sperm DNA ml-1 and $1 \times 10^{6}$ c.p.m. labelled probe) was added and the membranes were incubated overnight at $42^{\circ} \mathrm{C}$. The membranes were washed in $1 \times \mathrm{SSC}, 0.1 \%(\mathrm{w} / \mathrm{v}) \mathrm{SDS}$, $0.1 \%(\mathrm{w} / \mathrm{v})$ sodium pyrophosphate at $42^{\circ} \mathrm{C}$ for $15 \mathrm{~min}$, followed by consecutive washes in $0.1 \times \mathrm{SSC}, 0.1 \%(\mathrm{w} / \mathrm{v})$ SDS, $0.1 \%(\mathrm{w} / \mathrm{v})$ sodium pyrophosphate at $42^{\circ} \mathrm{C}$ and $47^{\circ} \mathrm{C}$ for $15 \mathrm{~min}$ each. After washing, the filters were exposed to a phosphoimager cassette. After exposure (2-24 h), the cassette was scanned using a phosphoimager (Bio-Rad). After northern blot analyses, the size of the RNA transcripts was determined based on relative migration of RNA molecular mass markers (Roche, Indianapolis, IN). After hybridization for PAI-1 or PAI-2, the membranes were stripped and reprobed with the [32P]-labelled RPL19 cDNA. Preliminary experiments demonstrated that RPL19 mRNA abundance in preovulatory bovine follicles and new corpora lutea is not regulated by the gonadotrophin surge (data not shown). Relative densitometric units for PAI-1 and PAI-2 were quantified and adjusted relative to RPL19 mRNA expression using Molecular Analyst Version 1.5 software (Bio-Rad). Preliminary northern blot experiments demonstrated that the hybridization and washing conditions used in subsequent dotblot analyses were specific and yielded hybridization to single transcripts of the expected size for each mRNA of interest. Preliminary experiments also demonstrated that an increase in hybridization intensity was detected after hybridization of each cDNA to increasing amounts of sample RNA $(1-10 \mu \mathrm{g})$.

\section{In situ hybridization}

Follicles were cut on a Leica cryostat (W. Nuhsbaum, McHenry, IL) into $12 \mu \mathrm{m}$ saggital sections and mounted onto positively charged slides (Fisher Scientific, Chicago, IL). A saggital section allows a view of the types of cell contained at both the apex and the base of the follicle. Before hybridization, the sections were prewarmed to room temperature for $10 \mathrm{~min}$, fixed in $3.7 \%(\mathrm{v} / \mathrm{v})$ formaldehyde in PBS for $5 \mathrm{~min}$, rinsed twice in $2 \times$ SSC for $2 \mathrm{~min}$ each, incubated in $0.25 \%(\mathrm{v} / \mathrm{v})$ acetic anhydride in $0.1 \mathrm{~mol}$ triethanolamine- $\mathrm{HCl} \mathrm{I}^{-1}$ ( $\mathrm{pH}$ 8.0) for $10 \mathrm{~min}$, dehydrated in increasing concentrations of ethanol (70, 80, 95 and 100\%; all $\mathrm{v} / \mathrm{v}$ ) for $2 \mathrm{~min}$ each, delipidated in absolute chloroform for 5 min, rinsed in 100\% and 95\% ethanol for 2 min each, and air dried for $1 \mathrm{~h}$. Hybridizations for each mRNA were performed on serial sections in triplicate using antisense and sense (negative controls) [ $\left.{ }^{35} \mathrm{~S}\right]$ - or [ $\left.{ }^{33} \mathrm{P}\right]$-labelled cRNA probes generated from previously described PAI- 1 and PAI-2 CDNAs. Both antisense and sense [ $\left.{ }^{35} \mathrm{~S}\right]$ UTP $\left(1250 \mathrm{Ci} \mathrm{mmol}^{-1}\right.$; NEN ${ }^{\circledR}$ Life Science Product; PAI-1) or [ $\left.{ }^{33} \mathrm{P}\right]$ UTP $\left(3000 \mathrm{Ci} \mathrm{mmol}^{-1}\right.$; PAI-2) cRNA probes were generated using linearized cDNA templates and an in vitro transcription kit (Stratagene) according to the manufacturer's directions. Plasmid DNA containing the shorter (247 bp) PAI-2 cDNA was used as a template for cRNA synthesis and hybridized to follicle sections. Both PAI-2 cDNAs yielded identical results in northern blot analyses (data not shown). The transcription reaction was incubated at $37^{\circ} \mathrm{C}$ for $1 \mathrm{~h}$ and template DNA was removed by incubation with $20 \mathrm{U}$ RNase-free DNase (Stratagene) at $37^{\circ} \mathrm{C}$ for $15 \mathrm{~min}$. After DNase treatment, the reaction was diluted to $100 \mu \mathrm{l}$ with NETS and unincorporated radionucleotides were removed as described above. Before hybridization, labelled probes were diluted in hybridization buffer to a concentration of $1.0 \times 10^{6}$ c.p.m. $\mathrm{ml}^{-1}$. Hybridization buffer included 50\% (v/v) formamide, $0.3 \mathrm{~mol}$ $\mathrm{NaCl} \mathrm{I}^{-1}, \quad 10 \mathrm{mmol}$ Tris ${ }^{-1} \quad(\mathrm{pH} 8), 1 \mathrm{mmol}$ EDTA I-1,

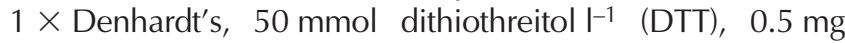
yeast tRNA ml and $10 \%(\mathrm{w} / \mathrm{v})$ dextran sulphate. Hybridizations were performed by adding $60 \mu \mathrm{l}$ diluted probe 
per slide and incubating the slide in a humidified oven at $55^{\circ} \mathrm{C}$ for $16 \mathrm{~h}$. After hybridization, the slides were washed twice by shaking in $2 \times$ SSC for $15 \mathrm{~min}$ at room temperature and were treated with RNase-A (50 $\mathrm{gg} \mathrm{ml}^{-1}$ in $2 \times \mathrm{SSC}$ ) for $1 \mathrm{~h}$ at $37^{\circ} \mathrm{C}$. The slides were washed at $55^{\circ} \mathrm{C}$ in $2 \times$ SSC containing $0.1 \%$ (v/v) $\beta$-mercaptoethanol (BME) for $15 \mathrm{~min}, 1 \times \mathrm{SSC} / 0.1 \%(\mathrm{v} / \mathrm{v})$ BME for $15 \mathrm{~min}, 1 \times \mathrm{SSC} / 50 \%(\mathrm{v} / \mathrm{v})$ formamide/0.1\% (v/v) BME for $30 \mathrm{~min}$, and twice in $0.1 \times \mathrm{SSC} / 0.1 \%(\mathrm{v} / \mathrm{v}) \mathrm{BME}$ for $15 \mathrm{~min}$. The slides were dehydrated in increasing ethanol concentrations $(60,80,95$ and 100\%), air dried for $1 \mathrm{~h}$ and dipped in 50\% (v/v) NTB-2 emulsion (Eastman Kodak, Rochester, NY). Slides were exposed to autoradiographic emulsion for either 10 days (PAI-1) or 50 days (PAI-2) at $4^{\circ} \mathrm{C}$ and developed, followed by counterstaining with haematoxylin and eosin. Exposure time for detection of a given mRNA was the same for all time points. Digital brightfield and dark-field images were acquired on a Leica research microscope equipped with SPOT Model 1.1.0 camera and Version 3.2.4 software (W. Nuhsbaum, McHenry, IL).

\section{Follicle homogenization procedure and chromogenic PAl assay}

Follicles were homogenized using procedures previously described by Murdoch and McCormick (1992). In brief, the apical or basal sections of follicles were homogenized using a polytron homogenizer (Fisher Scientific) in $800 \mu \mathrm{l}$ of $10 \mathrm{mmol}$ calcium chloride $\mathrm{I}^{-1}$ and $0.25 \%(\mathrm{v} / \mathrm{v})$ Triton-X100. The homogenates were centrifuged at $9000 \mathrm{~g}$ for $30 \mathrm{~min}$ at $4^{\circ} \mathrm{C}$ and the supernatants were collected and frozen at $-20^{\circ} \mathrm{C}$ until assayed.

Two chromogenic assays were required to determine quantitatively the plasminogen activator inhibitor (PAI-1 and PAI-2) activity present in the above samples. In the first assay, endogenous plasminogen activator activity (tPA plus uPA) was measured. Dow et al. (2002) reported changes in endogenous plasminogen activator activity. In the second assay, a fixed amount of exogenous uPA was added to the samples and allowed to react with the PAIs. The residual plasminogen activator activity was determined and the PAI activity was expressed as a percentage of plasminogen activator activity (endogenous and exogenous) quenched in each sample. In both assays, the endogenous or residual plasminogen activator activity was quantified using a procedure described by Coleman and Green (1981). A sample in which plasminogen was omitted as a substrate was used as a negative control. Standard curves using a plasminogen activator standard (uPA; Sigma Chemical Co., St Louis, MO) were used to interpolate plasminogen activator activity (endogenous or residual) in samples. Preliminary experiments established that an increase in plasminogen activator and PAI activity was detected with increasing amounts of sample protein (25-200 $\mu \mathrm{g})$. Each sample was run in duplicate for both assays and all samples were run in a single assay. The intra-assay coefficient of variation was $8.6 \%$. Validation of the PAI activity assay has been reported previously (Politis et al., 1990; Pandolfi et al., 2001).

\section{Statistical analysis}

Differences in mRNA abundance or PAI activity were determined by one-way ANOVA using the General Linear Models procedure of SAS (Version 8.0). For PAI activity, percentages were arcsine-transformed before statistical analysis. Individual comparisons of mean RNA concentrations or PAI activity were performed using Fisher's protected least significant differences test. When heterogeneity of variance was detected, data were log-transformed before statistical analysis.

\section{Results}

Regulation of PAI-1 and PAI-2 mRNA abundance during the periovulatory period

mRNA for PAI-1 was detected as a single transcript of $2.9 \mathrm{~kb}$ (Fig. 1a). The abundance of mRNA for PAl-1 increased after the gonadotrophin surge (Fig. 1b; $P<0.05$ ), with the highest mRNA abundance detected in follicles collected at about the time of ovulation (24 h) and in early corpora lutea $(48 \mathrm{~h})$. There was also a transient significant increase in PAI-1 mRNA in follicles collected at $6 \mathrm{~h}$ $(P<0.05)$, but expression then decreased to pre-surge concentrations by $12 \mathrm{~h}$ (Fig. $1 \mathrm{~b}$ ).

The gonadotrophin surge also upregulated PAI-2 mRNA expression in bovine periovulatory follicular and luteal tissue. A predominant transcript of $1.9 \mathrm{~kb}$ for PAI-2 was detected by northern blot analysis (Fig. 2a). Relative abundance of PAI-2 mRNA was increased transiently at $6 \mathrm{~h}$ $(P<0.05)$, but expression had decreased to pre-surge values in follicles collected at $12 \mathrm{~h}$. Subsequently, PAI-2 mRNA abundance also increased in $24 \mathrm{~h}$ follicles and was increased further in new corpora lutea (48 h; $P<0.05$; Fig. 2b) collected after GnRH injection.

\section{Localization of PAI-1 and PAI-2 mRNAs in preovulatory bovine follicles}

The cell-specific regulation of expression of PAI- 1 and PAI-2 mRNA in response to the gonadotrophin surge was distinct. mRNA for PAI-1 was detected in the thecal layer at all times examined (Fig. 3d-f; 0, 6 and $24 \mathrm{~h}$ depicted). However, a low expression was also observed in the granulosa cell layer in follicles collected at about the time of ovulation (Fig. 3f; 24 h). In contrast, expression of PAl-2 mRNA was localized specifically to the granulosa cell layer of preovulatory follicles collected at 6 and $24 \mathrm{~h}$ (Fig. 4e,f). Significant expression in the thecal layer and adjacent ovarian stroma was not detected.

\section{Effect of the gonadotrophin surge on PAl activity in preovulatory bovine follicles}

Exogenous UPA activity added to preovulatory follicle homogenates (apex and base) was inhibited by $60-80 \%$, indicating the presence of significant endogenous PAI activity in follicles collected during the periovulatory period 
(a) PAI-1

$28 \mathrm{~S}$ $18 S$ (a)

$28 \mathrm{~S}$

$18 \mathrm{~S}$
PAI-2

\section{- 0 이 RPL19}

$0 \quad 612182448$

Time after $\mathrm{GnRH}$ injection (h)

(b)

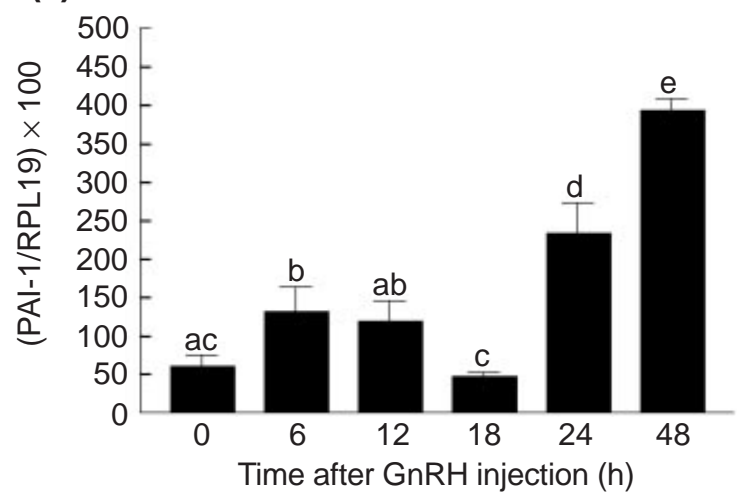

Fig. 1. Effect of a GnRH-induced gonadotrophin surge on abundance of plasminogen activator inhibitor 1 (PAI-1) mRNA in periovulatory bovine follicular and luteal tissue. (a) Northern blot analysis of expression of PAI-1 mRNA: note hybridization to a single $2.9 \mathrm{~kb}$ transcript. (b) Effect of the preovulatory gonadotrophin surge on relative abundance of PAI-1 mRNA in preovulatory bovine follicles and new corpora lutea. Data in (b) are expressed as relative units (PAI-1 mRNA per unit ribosomal protein L-19 $($ RPL19) $m R N A) \times 100$. Data are mean \pm SE. ${ }^{\text {a-e }}$ Times without a common superscript are significantly different $(P<0.05)$.

(Fig. 5). However, PAl activity in the preovulatory follicle apex and base was not regulated temporally by the gonadotrophin surge (Fig. 5).

\section{Discussion}

Controlling and focusing extracellular proteolytic activity is essential for many reproductive processes, including ovulation. There is a marked preovulatory increase in both mRNA abundance and activity for tPA and UPA in preovulatory bovine follicles (Dow et al., 2002). The induction of PAIs is thought to be one of the key means for regulation of plasmin-mediated proteolysis initiated by the plasminogen activators. However, the regulation of the PAIs in preovulatory bovine follicles during the periovulatory period has not been reported. The results of the present study show clearly that PAI- 1 and PAI-2 mRNAs were upregulated in a cell-specific way in response to the gonadotrophin surge, but temporal changes in PAI activity

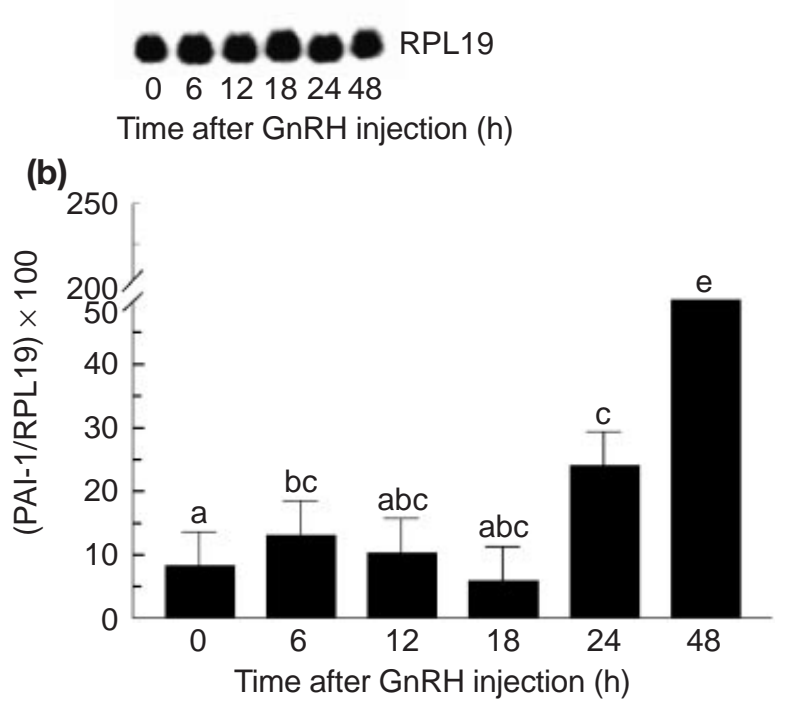

Fig. 2. Effect of a GnRH-induced gonadotrophin surge on abundance of plasminogen activator inhibitor 2 (PAI-2) mRNA in periovulatory bovine follicular and luteal tissue. (a) Northern blot analysis of expression of PAI-2 mRNA: note hybridization predominantly to a single $1.9 \mathrm{~kb}$ transcript. (b) Effect of the preovulatory gonadotrophin surge on relative abundance of PAI-2 mRNA in preovulatory bovine follicles and new corpora lutea. Data in (b) are expressed as relative units (PAI-2 mRNA per unit ribosomal protein L-19 $($ RPL19) $\mathrm{mRNA}) \times 100$. As a result of heterogeneity of variance, values for PAI-2 mRNA were log-transformed before analysis. Data shown as mean \pm average SE. a-eTimes without a common superscript are significantly different $(P<0.05)$.

were not detected. Furthermore, the regulation of PAI-1 and PAI-2 mRNAs and PAI activity observed are distinct from reports in other species to date.

A transient increase in the abundance of PAI-1 mRNA was observed within $6 \mathrm{~h}$ after the gonadotrophin surge, with increased expression detected at about the time of ovulation (24 $\mathrm{h}$ follicles) and in new corpora lutea. This finding is in contrast to reported changes in PAI-1 mRNA abundance in preovulatory rat and monkey follicles in response to hCG administration. In the above species, PAI-1 mRNA is upregulated transiently but subsequently decreases in preovulatory follicles at about the time of ovulation (Liu et al., 1991; Peng et al., 1993). Furthermore, high expression of tPA mRNA continues in preovulatory rat and monkey follicles at about the time of ovulation, several hours after the decrease in PAI-1 mRNA. At about the time of 

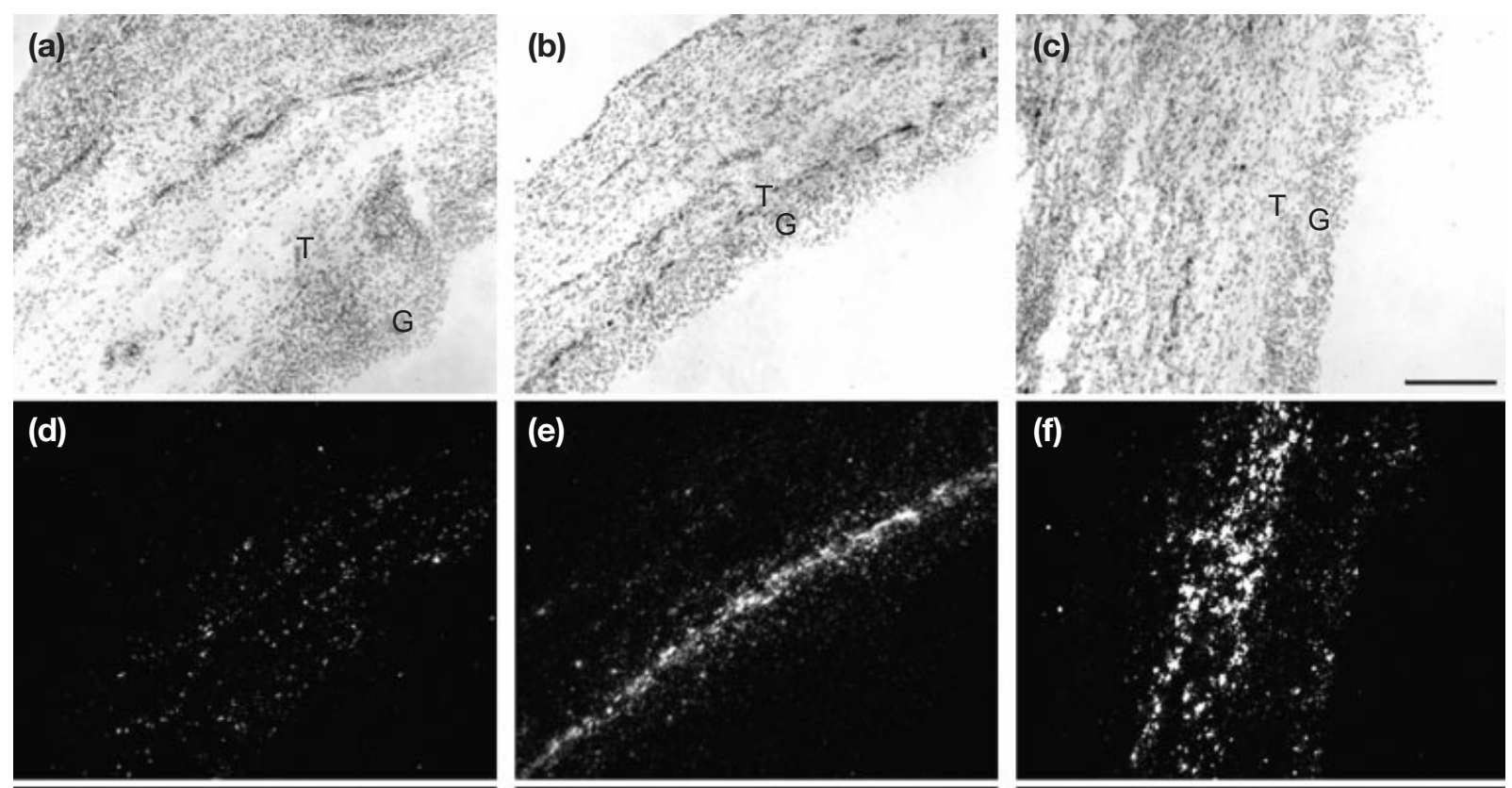

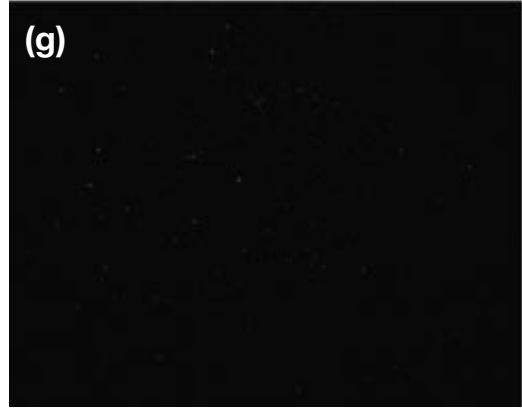

0

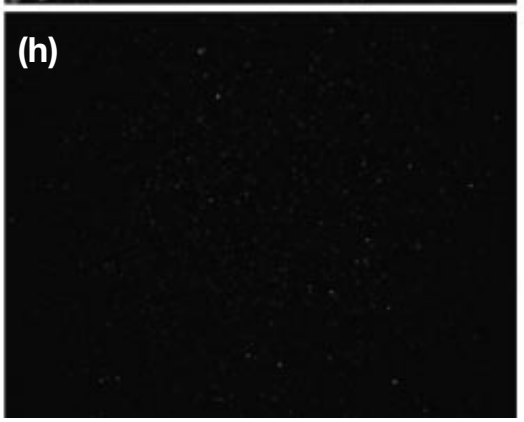

6

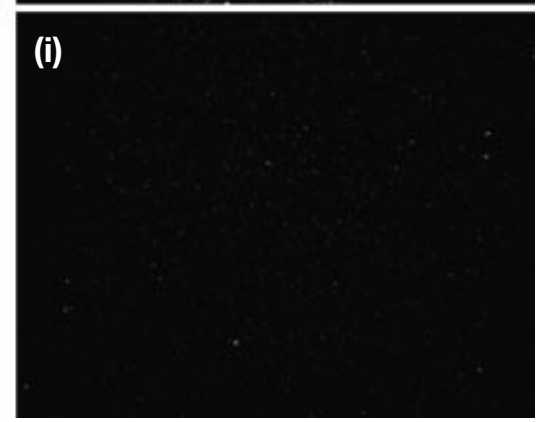

24

Time after GnRH injection (h)

Fig. 3. In situ localization of plasminogen activator inhibitor 1 (PAI-1) mRNA within periovulatory bovine follicles collected at 0, 6 and $24 \mathrm{~h}$ after GnRH injection. Representative bright-field micrographs of preovulatory follicles collected at (a) $0 \mathrm{~h}$, (b) $6 \mathrm{~h}$ and (c) $24 \mathrm{~h}$, and stained with haematoxylin and eosin. Representative dark-field micrographs of the corresponding bright-field sections of preovulatory follicles collected at (d) $0 \mathrm{~h}$, (e) $6 \mathrm{~h}$ and ( $\mathrm{f}) 24 \mathrm{~h}$, and hybridized with a [ $\left.{ }^{35} \mathrm{~S}\right]$-labelled antisense PAI-1 cRNA. Representative dark-field micrographs of corresponding adjacent serial sections of the same follicles collected at (g) $0 \mathrm{~h}$, (h) $6 \mathrm{~h}$ and (i) $24 \mathrm{~h}$, and hybridized with a [ $\left.{ }^{35} \mathrm{~S}\right]$-labelled sense PAI-1 cRNA ( $n=3$ per time; total $=9$ ). Note highest expression of PAI-1 mRNA in the thecal layer (T), with additional localization in the granulosa cell layer (G) of follicles collected at $24 \mathrm{~h}$. Scale bar represents $250 \mu \mathrm{m}$.

ovulation, plasminogen activator activity in preovulatory pig follicles increases, with a concomitant decrease in PAI activity (Politis et al., 1990). This finding indicates that a decrease in PAI-1 with continued PA activity may play a role in regulation of follicular rupture. In contrast, PAI-1 mRNA is not upregulated until after ovulation in mice (Leonardsson et al., 1995; Hagglund et al., 1996). In the present study, PAI-1 mRNA was localized primarily to the thecal layer, with lower expression observed in the adjacent granulosa cell layer of preovulatory follicles collected at $24 \mathrm{~h}$. In monkeys and rats, PAI-1 mRNA was also localized primarily to the thecal layer (Liu, 1999), but additional expression has also been observed in the ovarian stroma of preovulatory rat follicles (Peng et al., 1993).
A significant increase in PAI-2 mRNA was also observed in preovulatory bovine follicles at about the time of follicular rupture (24 h) and PAI-2 mRNA was localized specifically to the granulosa cell layer. Very limited information is available regarding the temporal and cell-specific regulation of PAI-2 mRNA during the periovulatory period in other species. mRNA for PAl-2 has been detected in both human and mouse ovarian tissues. Both human cumulus cells and granulosa-luteal cells collected from patients (36 h after hCG administration; a few hours before ovulation) undergoing IVF express PAI-2 mRNA (Piquette et al., 1993). A small increase in PAl-2 mRNA abundance was also observed in mouse ovaries at $4 \mathrm{~h}$ after hCG injection. The localization of PAI-2 mRNA in the mouse ovary was distinct from that 

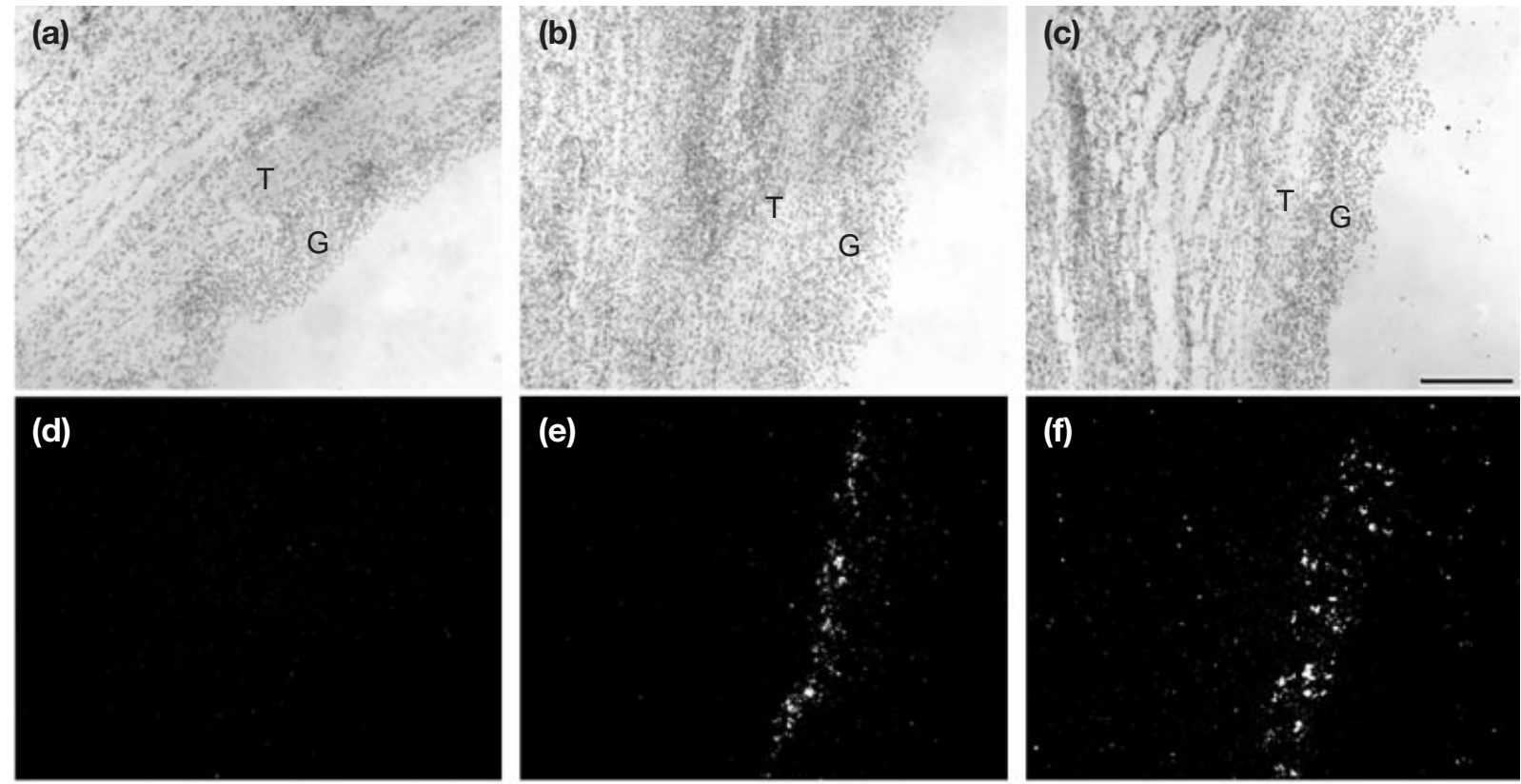

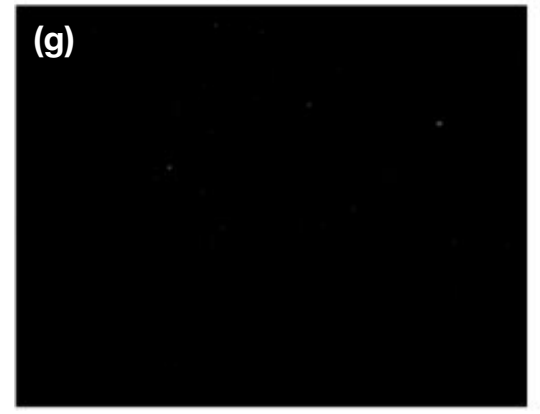

0

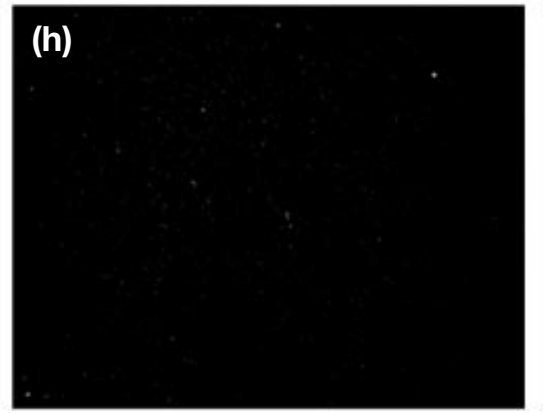

6

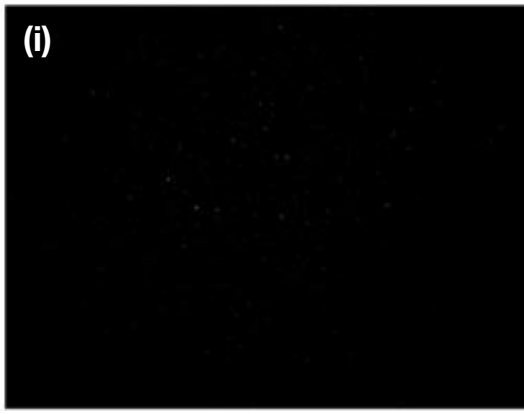

24

Time after GnRH injection (h)

Fig. 4. In situ localization of plasminogen activator inhibitor 2 (PAI-2) mRNA within periovulatory bovine follicles collected at 0,6 and $24 \mathrm{~h}$ after $\mathrm{GnRH}$ injection. Representative bright-field micrographs of preovulatory follicles collected at (a) $0 \mathrm{~h}$, (b) $6 \mathrm{~h}$ and (c) $24 \mathrm{~h}$, and stained with haematoxylin and eosin. Representative dark-field micrographs of the corresponding brightfield sections of preovulatory follicles collected at (d) $0 \mathrm{~h}$, (e) $6 \mathrm{~h}$ and (f) $24 \mathrm{~h}$, and hybridized with [ ${ }^{33} \mathrm{P}$ ]-labelled antisense PAI-2 cRNAs. Representative dark-field micrographs of corresponding adjacent serial sections of the same follicles collected at (g) $0 \mathrm{~h}$, (h) $6 \mathrm{~h}$ and (i) $24 \mathrm{~h}$, and hybridized with [ $\left.{ }^{33} \mathrm{P}\right]$-labelled sense PAI-2 cRNAs $(n=3$ per time; total $=9$ ). Note localization of PAI-2 mRNA to the granulosa cell layer (G) of follicles collected at 6 and 24 h. T: thecal layer. Scale bar represents $250 \mu \mathrm{m}$.

observed in cattle and was restricted primarily to a few individual cells within the thecal layer that were thought to be macrophages (Leonardsson et al., 1995).

PAI-2 is a major product of macrophages and monocytes in response to inflammatory conditions (Schwartz et al., 1988; Gyetko et al., 1992). Furthermore, the two different forms of PAI-2 (extracellular and intracellular) in monocytes probably have distinct functions. The extracellular form inhibits UPA activity, whereas the predominant intracellular form inhibits tumour necrosis factor $\alpha$ (TNF- $\alpha$ )-directed apoptosis (Dickinson et al., 1995, 1998). Plasmin production at the site of follicle rupture in preovulatory sheep follicles facilitates liberation of membrane-anchored TNF- $\alpha$ and subsequent apoptosis of ovarian surface epithelial cells (Murdoch, 1995a,b, 1998, 1999; Murdoch et al., 1997). Although the presence of the two forms of PAI-2 in bovine granulosa cells has not been established, it is possible that intracellular PAI-2 may have a protective role against TNF$\alpha$-directed apoptosis in the granulosa cell layer of preovulatory bovine follicles.

Formation of the corpus luteum involves marked biochemical and morphological processes including luteinization, angiogenesis and cellular proliferation and migration. In the present study, the highest relative abun- 


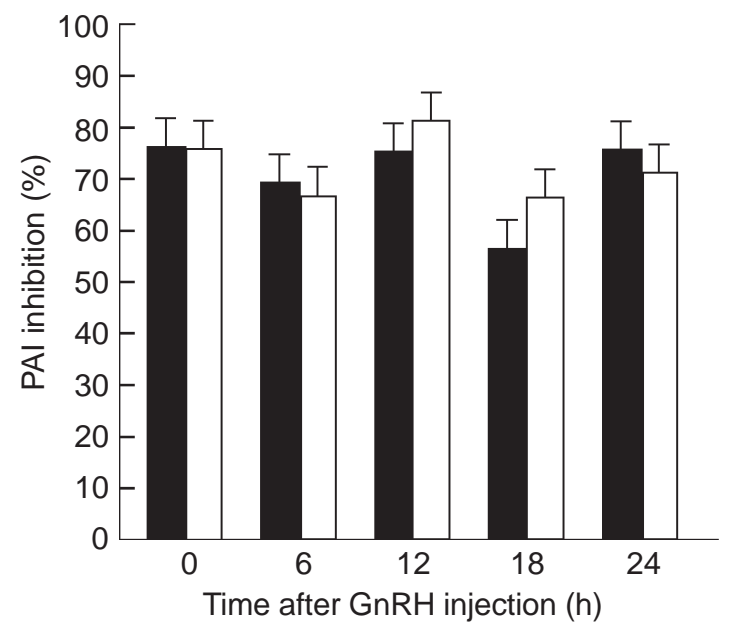

Fig. 5. Detection of total plasminogen activator inhibitor activity (PAI-1 and PAI-2) in homogenates of the apex ( $\square$ ) and base ( $\square$ ) of periovulatory bovine follicles using a chromogenic assay. Data are expressed as percentage PAI activity per $100 \mu \mathrm{g}$ protein. As a result of heterogeneity of variance, the data were log-transformed. Percentages were arcsine-transformed before statistical analysis. Data are mean \pm average SE $(n=5-6$ per time). PAI activity in the preovulatory follicle apex and base were not regulated in response to the gonadotrophin surge.

dance of PAI-1 and PAI-2 mRNA was observed in tissue collected during corpus luteum formation. Furthermore, it is possible that the increased abundance of PAI-1 and PAI-2 mRNA detected at about the time of ovulation may in fact be more relevant to regulation of luteal development. In rats, PAI-1 mRNA is localized adjacent to uPA-expressing capillaries of the early corpus luteum and is thought to play an important role in the regulation of angiogenesis (Bacharach et al., 1992). Studies using PAI-1 deficient mice have shown the absolute requirement for $\mathrm{PAI}-1$ during tumour-induced angiogenesis (Bajou et al., 1998; Gutierrez et al., 2000). The role of PAI-2 (intracellular or extracellular) during corpus luteum formation is unclear. More investigation will be critical to understanding the exact roles of PAI-1 and PAI-2 during the periovulatory period in cattle.

Significant PAI activity (PAI-1 and PAI-2) was detected in the apex and base of preovulatory bovine follicles. However, no temporally or spatially significant changes in $\mathrm{PAI}$ activity were detected in response to the gonadotrophin surge. Increased tPA mRNA abundance and activity have been observed during the periovulatory period in preovulatory bovine follicles (Dow et al., 2002). Furthermore, tPA activity is spatially regulated in preovulatory bovine follicles after the gonadotrophin surge. In the follicle apex, tPA activity is increased in response to the gonadotrophin surge and remains high until $24 \mathrm{~h}$ later. In contrast, tPA activity in the follicle base peaks within $12 \mathrm{~h}$ after the gonadotrophin surge and decreases to pre-surge values by $24 \mathrm{~h}$ (Dow et al., 2002). A differential increase in PAl activity was not detected in the base of preovulatory bovine follicles at about the time of follicular rupture. Therefore, the differential upregulation of tPA activity in the follicular apex versus the base is not likely to be a result of regional differences in upregulation of PAl activity in response to the gonadotrophin surge. This difference in the regulation of plasminogen activator (tPA) and PAI abundance may provide a temporal and spatial window of increased plasminogen activator activity that may help to facilitate follicular rupture.

In conclusion, we have demonstrated that PAI-1 and PAI-2 mRNAs are upregulated in preovulatory bovine follicles in response to the preovulatory gonadotrophin surge with maximal expression during corpus luteum formation. Furthermore, the temporal and spatial regulation of PAI-1 and PAI-2 mRNAs in preovulatory bovine follicles in response to the gonadotrophin surge was distinct from reports to date in other species. Further investigation will be required to elucidate the precise physiological roles of PAI1 and PAI-2 during the periovulatory period in cattle.

The authors would like to thank Isam Qahwash for his help with tissue collection. The authors are grateful to Theresa Doerr for her clerical assistance. The authors would like to thank Jim Ireland and Janet Ireland for reagents and assistance with the $\mathrm{LH}$ radioimmunoassay. This work was supported by USDA 98-35203-6226 (G. W. Smith) and the Michigan Agricultural Experiment Station.

\section{References}

Bacharach E, Itin A and Keshet E (1992) In vivo patterns of expression of urokinase and its inhibitor PAI-1 suggest a concerted role in regulating physiological angiogenesis Proceedings National Academy of Sciences USA $8910686-10690$

Bajou K, Noel A, Gerard RD et al. (1998) Absence of host plasminogen activator inhibitor 1 prevents cancer invasion and vascularization Nature Medicine 4 923-928

Coleman PL and Green GD (1981) A sensitive, coupled assay for plasminogen activator using a thiol ester substrate for plasmin Annals of the New York Academy of Science 370 617-626

Dickinson JL, Bates EJ, Ferrante A and Antalis TM (1995) Plasminogen activator inhibitor type 2 inhibits tumor necrosis factor alpha-induced apoptosis. Evidence for an alternate biological function Journal of Biological Chemistry 27027 894-27904

Dickinson JL, Norris BJ, Jensen PH and Antalis TM (1998) The C-D interhelical domain of the serpin plasminogen activator inhibitor-type 2 is required for protection against TNF $\alpha$-induced apoptosis Cell Death and Differentiation 5 163-171

Dow MPD, Bakke LJ, Cassar CA, Peters MW, Pursley JR and Smith GW (2002) Gonadotropin surge-induced upregulation of the plasminogen activators (tissue plasminogen activator and urokinase plasminogen activator) and urokinase plasminogen activator receptor within bovine periovulatory follicular and luteal tissue Biology of Reproduction $\mathbf{6 6}$ $413-421$

Gutierrez LS, Schulman A, Brito-Robinson T, Noria F, Ploplis VA and Castellino FJ (2000) Tumor development is retarded in mice lacking the gene for urokinase-type plasminogen activator or its inhibitor plasminogen activator inhibitor-1 Cancer Research 60 5839-5847

Gyetko MR, Shollenberger SB and Sitrin RG (1992) Urokinase expression in mononuclear phagocytes: cytokine-specific modulation by interferongamma and tumor necrosis factor-alpha Journal of Leukocyte Biology 51 256-263

Hagglund AC, Ny A, Liu K and Ny T (1996) Coordinated and cell-specific induction of both physiological plasminogen activators creates 
functionally redundant mechanisms for plasmin formation during ovulation Endocrinology 137 5671-5677

Holmberg L, Lecander I, Persson B and Astedt B (1978) An inhibitor from placenta specifically binds urokinase and inhibits plasminogen activator released from ovarian carcinoma in tissue culture Biochimica et Biophysica Acta 544 128-137

Jimenez Krassel F, Binelli M, Tucker HA and Ireland JJ (1999) Effect of longterm infusion with recombinant growth hormone-releasing factor and recombinant bovine somatotropin on development and function of dominant follicles and corpora lutea in Holstein cows Journal of Dairy Science 82 1917-1926

Kruithof EK, Vassalli JD, Schleuning WD, Mattaliano RJ and Bachmann F (1986) Purification and characterization of a plasminogen activator inhibitor from the histiocytic lymphoma cell line U-937 Journal of Biological Chemistry 26111 207-11 213

Kruithof EK, Tran Thang C, Gudinchet A, Hauert J, Nicoloso G, Genton C, Welti $\mathbf{H}$ and Bachmann $\mathbf{F}$ (1987) Fibrinolysis in pregnancy: a study of plasminogen activator inhibitors Blood 69 460-466

Lecander I, Roblin R and Astedt B (1984) Differential inhibition of two molecular forms of melanoma cell plasminogen activator by a placental inhibitor British Journal of Haematology 57 407-412

Leonardsson G, Peng XR, Liu K, Nordstrom L, Carmeliet P, Mulligan R, Collen D and Ny T (1995) Ovulation efficiency is reduced in mice that lack plasminogen activator gene function: functional redundancy among physiological plasminogen activators Proceedings National Academy of Sciences USA 9212 446-12 450

Liu YX (1999) Regulation of the plasminogen activator system in the ovary Biological Signals and Receptors 8 160-177

Liu YX, Peng XR and Ny T (1991) Tissue-specific and time-coordinated hormone regulation of plasminogen-activator-inhibitor type I and tissuetype plasminogen activator in the rat ovary during gonadotropininduced ovulation European Journal of Biochemistry 195 549-555

Loskutoff DJ, Sawdey M and Mimuro J (1988) Type I plasminogen activator inhibitor. In Progress in Haemostasis and Thrombosis pp 87-115 Ed. BS Coller. Saunders, Philadelphia

Matteri RL, Roser JF, Baldwin DM, Lipovetsky V and Papkoff H (1987) Characterization of a monoclonal antibody which detects luteinizing hormone from diverse mammalian species Domestic Animal Endocrinology 4 157-165

Murdoch WJ (1995a) Endothelial cell death in preovulatory ovine follicles: possible implication in the biomechanics of rupture Journal of Reproduction and Fertility 105 161-164

Murdoch WJ (1995b) Programmed cell death in preovulatory ovine follicles Biology of Reproduction 53 8-12

Murdoch WJ (1998) Regulation of collagenolysis and cell death by plasmin within the formative stigma of preovulatory ovine follicles Journal of Reproduction and Fertility 113 331-336

Murdoch WJ (1999) Plasmin-tumour necrosis factor interaction in the ovulatory process Journal of Reproduction and Fertility Supplement $\mathbf{5 4}$ 353-358
Murdoch WJ and McCormick RJ (1992) Enhanced degradation of collagen within apical versus basal wall of ovulatory ovine follicle American Journal of Physiology 263 E221-E225

Murdoch WJ, Colgin DC and Ellis JA (1997) Role of tumor necrosis factoralpha in the ovulatory mechanism of ewes Journal of Animal Science $\mathbf{7 5}$ 1601-1605

Pandolfi A, Cetrullo D, Polishuck R, Alberta MM, Calafiore A, Pellegrini G, Vitacolonna E, Capani F and Consoli A (2001) Plasminogen activator inhibitor type 1 is increased in the arterial wall of type II diabetic subjects Arteriosclerosis, Thrombosis and Vascular Biology 21 1378-1382

Peng XR, Hsueh AJ and Ny T (1993) Transient and cell-specific expression of tissue-type plasminogen activator and plasminogen-activatorinhibitor type 1 results in controlled and directed proteolysis during gonadotropin-induced ovulation European Journal of Biochemistry 214 $147-156$

Piquette GN, Crabtree ME, el-Danasouri I, Milki A and Polan ML (1993) Regulation of plasminogen activator inhibitor-1 and -2 messenger ribonucleic acid levels in human cumulus and granulosa-luteal cells Journal of Clinical Endocrinology and Metabolism 76 518-523

Politis I, Srikandakumar A, Turner JD, Tsang BK, Ainsworth L and Downey BR (1990) Changes in and partial identification of the plasminogen activator and plasminogen activator inhibitor systems during ovarian follicular maturation in the pig Biology of Reproduction 43 636-642

Pursley JR, Mee MO and Wiltbank MC (1995) Synchronization of ovulation in dairy cows using PGF2 alpha and GnRH Theriogenology 44 915-923

Pursley JR, Kosorok MR and Wiltbank MC (1997) Reproductive management of lactating dairy cows using synchronization of ovulation Journal of Dairy Science 80 301-306

Sambrook J, Fritsch EF and Maniatis T (1989) Extraction, purification and analysis of messenger RNA from eukaryotic cells. In Molecular Cloning: A Laboratory Manual pp 7.53-57.55 Ed. C Nolan. Cold Spring Harbor Laboratory Press, Plainview

Schleuning WD, Medcalf RL, Hession C, Rothenbuhler R, Shaw A and Kruithof EK (1987) Plasminogen activator inhibitor 2: regulation of gene transcription during phorbol ester-mediated differentiation of U-937 human histiocytic lymphoma cells Molecular and Cellular Biology 7 4564-4567

Schwartz BS, Monroe MC and Levin EG (1988) Increased release of plasminogen activator inhibitor type 2 accompanies the human mononuclear cell tissue factor response to lipopolysaccharide Blood $\mathbf{7 1}$ 734-741

Received 17 September 2001.

First decision 15 November 2001.

Revised manuscript received 1 January 2002.

Accepted 23 January 2002. 